\title{
Effect of Wound Care Using Robusta Coffee Powders on Diabetic Ulcer Healing in Sekarwangi Hospital Sukabumi
}

\author{
Yeni Yulianti ${ }^{1}$, Kusman Ibrahim ${ }^{2}$, Titis Kurniawan ${ }^{2}$ \\ ${ }^{1}$ Stikes Sukabumi, ${ }^{2}$ Faculty of Nursing, Universitas Padjadjaran \\ Email:yeniyulianti_22@yahoo.com
}

Submitted: 7-8-2017 Accepted: 30-4-2018 Published: 30-4-2018

\begin{abstract}
Diabetic ulcer is one of the most disabling diabetic related complications. It requires specific wound care techniques that not only facilitate the healing process but also minimize the infection and other healing barriers. This study was aimed to identify the effect of wound care using Robusta coffee powders on diabetic ulcer healing. This quasi experiment with the Pretest-Posttest Control Group Design study involved 32 patients with diabetic foot ulcer who consecutively recruited from Sekarwangi Hospital in Sukabumi - West Java. Patients who met the criteria; GDS 70-250 mg/dl and never received wound care using Robusta Coffee Powder were equally divided into two groups (intervention group received wound care using Robusta Coffee powders and cleaned every two days, while the control group received daily conventional wound care). Wound healing process was measured using BatesJensen Wound Assessment Tool (BWAT) twice; pretest (week 0) and posttest (week $2^{\text {nd }}$ ). Data were analyzed using dependent and independent t-test. The results suggested there was no significant different of respondents' characteristics between both groups. The result showed that mean of posttest scores, either in intervention group or control group were significantly lower $(p=0.000)$ than the mean of pretest scores. Additionally, the different score between posttest and pretest in the intervention group $(16.25+4.768)$ was significantly higher $(\mathrm{p}=0.000)$ than that in the control group $(6.25+3.444)$. These findings indicated that the effect of wound care using Robusta Coffee powders on diabetic ulcer healing process is more evident than the conventional dressing. It is important for the hospital staffs to consider wound care using Robusta Coffee powders as a strategy in managing diabetic ulcer
\end{abstract}

Keywords: BWAT Scores, diabetic ulcer, gangrene, Robusta Coffee, wound healing 
Yeni Yulianti: Effects of Wound Care using Robusta Coffee Powders on Diabetic Ulcer Healing

\section{Introduction}

Diabetes mellitus (DM) is a group of metabolic disease characterized with hyperglycemia that occurs due to abnormalities of insulin secretion, insulin insufficiency or both (PERKENI, 2015). This disease currently becomes one of serious health problem in Indonesia. The data noted that Indonesia is one of top ten countries with highest population ages 20-79 years who suffer from DM in the world. In the year of 2010-2011, the number of people who suffer from DM in Indonesia ranges from 7-7.3 million and it predicted became double in 2030 (11.8-12 million people) (Shaw, Hughes, Lagan, Bell \& Stevenson, 2007; Whiting, Guariguata, Weil, \& Shaw, 2011).

Beside the number of diabetic patients that continuously increase, DM also identified as one chronic disease that frequently result in complications. One of the most common complications is diabetic ulcer. It is estimated that $15 \%$ of patients with diabetic will experience ulcer under lower extremities. According to some observation of the study in England among the neuropathic patients, the incident of occurrence ulcer diabetic gangrene at the beginning of the first year is about 7\%. Neuropathic, deformity, plantar high pressure, uncontrolled blood glucose level, and male gender are the contributing factors to ulceration occurrence. Meanwhile $7 \%$ up to $20 \%$ suffers of foot ulcer need to be amputated. Foot ulceration is the main cause around $85 \%$ of the amputation on lower extremity among patients with DM (Fryberg et al., 2006).

Management of diabetic ulcer/gangrene started from the early detection of diabetic foot disorder, metabolic control, mechanical control, control of vascular injuries, infection control and health education (PERKENI, 2015). Once diabetic ulcers occurred, wound care is one of vital components in managing diabetic ulcers. Diabetic foot ulcer characteristics require specific wound management that not only facilitates the healing processes but also able to prevent and fight the wound infections and others inhibiting factors that commonly found in patient with DM.

The development of wound care techniques currently has been in grant progress and some of them have already applied to overcome the drawbacks of the conventional wound care. One of the developed techniques is wound care using Modern Wound Dressing. Modern Wound Dressing effectively improves diabetic wound healing process with the higher costs effectiveness (Ismail et al., 2009). However, some of Modern Wound Dressing products are imported and might emerge the financial issues. Therefore, other wound care technique or methods that not only potent to improve diabetic healing process but also utilize the searchable and affordable price materials is compulsory.

In Indonesia, some natural products are commonly used as materials to treat the wound. One of the most common one is honey (Aftria, 2004). It has been reported that honey effectively improve wound healing including diabetic ulcer (Alam, Islam, Gan, \& Khalil, 2014). However, big varieties of honey in Indonesia cause difficulties in finding the pure and standardized honey product that met the criteria for wound care used (Martyarini \& Najatullah, 2011). Another natural product is coffee powders that commonly used to treat the wound by people who live in coffee field area (Yuwono, 2014).

Some literature suggested that coffee seeds contain of caffeine, an alkaloid compound xanthin and chlorogenic acids (CGA) including the polyphenol compounds that have antioxidant roles. These substances are higher in Robusta Coffee than Arabica coffee or the other plants (Johnston, Clifford, \& Morgan, 2003; Sukohar, Wirakusumah, \& Sastramihardja, 2013). The CGA in coffee have biological functions such as antibacterial, antioxidant, and anti-inflammation activity (Liang \& Kitts, 2015). These might provide benefits for improving diabetic ulcers conditions that commonly faced infection and healing problems. Additionally, coffee powders also minimized the malodor that commonly found in gangrene. It might further potentially improve patients' convenience.

Robusta Coffee not only commonly used as an materials for wound care as part of traditional medicine for some Indonesian people but also passed the pre-clinic test using animal in the laboratory setting. The laboratory test in alloxan-induced-mice 
Yeni Yulianti: Effects of Wound Care using Robusta Coffee Powders on Diabetic Ulcer Healing

noted that Robusta coffee powders speed up the wounds closure by increasing the number of lymphocytes, plasma cells, macrophages, fibroblasts, and the blood vessels that further enhance the healing process. Study in clinical setting already conducted by some researchers and found that this wound dressing technique was effectively improve diabetic ulcer healing (Kenisa \& Istiati, 2012; Susanto, Puradisastra, \& Ivone, 2010). However, those studies did not clearly explain the technique wound dressing applied and its healing measurement tool used. Therefore it is important to further identify the effect of wound care using Robusta Coffee Powders on diabetic ulcer healing in Sekarwangi Hospital Sukabumi."

\section{Method}

This research applied Quasi-experimental with pretest and posttest control group. As many as 32 DM patients with diabetic ulcer were consecutively recruited from Sekarwangi Hospital Sukabumi - West Java and then divided equally into two groups; intervention group (16 respondents) and control group (16 respondents). The intervention group received standard intervention for diabetic patient from hospital and received wound washed/clean and change the dressing every couple days, while the control group received the standard therapy for diabetic patients from hospital and received conventional wound care (using $\mathrm{NaCl} 0.9 \%$ gauze and/or Povidine iodine) as well as washed/clean and change the dressing every day.

The wound/diabetic ulcer healing was care using Robusta Coffee Powders as well as

measured twice in the pre intervention and two weeks after treatment applied using BatesJensen Wound Assessment Tool (BWAT). BWAT is a wound assessment tool developed by Barbara Bates Jensen (2001) consisted of 13 items to assess the wound including size, depth, edges, undermining, necrotic tissue type, amount of necrotic tissue, granulation and epithelialization tissue, exudate type and amount, surrounding skin color, peripheral tissue edema and induration. Each item has five categories with an associated score. It had been tested and had strong Inter-rater reliability $(0.91$ for time 1 and 0.92 for time 2, $p<.001$ ) (Pillen et al., 2009).

Before data collection run, the authors conducted the laboratory test to certify that the Coffee Robusta powders used were safe for wound care. This study applied the ethical principles and gained the ethical clearance from Universitas Padjadjaran Ethical Committee on May 3rd, 2017 Letter of ethical clearance No 566/UN6. C10/PN/2017.

Data collection was conducted on May 8rd. until July 4th, 2017 in Surgical Inpatient Ward and Out-Patient Department of Sekarwangi Hospital Sukabumi West - Java. The collected data were analyzed descriptively and tested for the normality. The normality test found that the data of wound healing score, either pretest or posttest in both groups were normally distributed. Further analysis conducted to identify the different of the wound healing score either pretest-posttest in each group (dependent t-test) or between groups (independent t-test).

\section{Result}

Table 1 Frequency, Percentage and Homogeneity of the Respondents' Characteristics in the Intervention Group and Control Group $(n=32)$

\begin{tabular}{|c|c|c|c|c|c|}
\hline \multirow[t]{3}{*}{ Characteristic } & \multicolumn{4}{|c|}{ Group } & \multirow[t]{3}{*}{$\mathbf{p}$} \\
\hline & \multicolumn{2}{|c|}{ Intervention } & \multicolumn{2}{|c|}{ Control } & \\
\hline & f & $\%$ & f & $\%$ & \\
\hline Age & & & & & 1.000 \\
\hline $50-60$ years & 12 & 75 & 15 & 93.75 & \\
\hline 60 years & 4 & 25 & 1 & 6.25 & \\
\hline Sex & & & & & 0.529 \\
\hline Male & 4 & 25 & 3 & 18.75 & \\
\hline
\end{tabular}


Yeni Yulianti: Effects of Wound Care using Robusta Coffee Powders on Diabetic Ulcer Healing

\begin{tabular}{lccccc}
\hline Female & 12 & 75 & 13 & 81.25 & \\
IMT & & & & & 0.350 \\
$<18.50$ & 1 & 6.25 & 2 & 12.5 & \\
$18.50-25.99$ & 15 & 93.75 & 14 & 87.5 & \\
GDS & & & & & 1.000 \\
$<200 \mathrm{mg} / \mathrm{dl}$ & 12 & 75 & 14 & 87.5 & \\
$200-250 \mathrm{mg} / \mathrm{dl}$ & 4 & 25 & 2 & 12.5 & \\
Wound Type & & & & & 0.585 \\
Post Debridement \& Amputation & 7 & 43.75 & 4 & 25 & \\
Ulcer $>4$ weeks & 9 & 56.25 & 12 & 75 & \\
Length of Ulcer & & & & & 1.000 \\
$1-4$ weeks & 7 & 43.75 & 8 & 50 & \\
$>4$ weeks & 9 & 56.25 & 8 & 50 & \\
Treatment & & & & & \\
Antibiotic \& Insulin & 15 & 93.75 & 15 & 93.75 & \\
Insulin & 1 & 6.25 & 1 & 6.25 & \\
\hline
\end{tabular}

Table 2 The Pre and Post Test Mean Scores and It's Different in Intervention and Control Group

\begin{tabular}{lccccc}
\hline \multicolumn{1}{c}{ BWAT Score } & $\begin{array}{c}\text { Average } \\
\text { (SD) }\end{array}$ & $\begin{array}{c}\text { Difference } \\
\text { (SD) }\end{array}$ & IK 95\% & t & p \\
\hline Intervention Group & & & & & \\
Pre Test Score & $44.44(5.621)$ & $15.75(1.247)$ & $13.09-18.40$ & 12.634 & 0.000 \\
$\begin{array}{l}\text { Post Test Score } \\
\text { Control Group }\end{array}$ & $28.69(7.209)$ & & & & \\
$\begin{array}{l}\text { Pretest Score } \\
\text { Posttest Score }\end{array}$ & $42.56(6.066)$ & $6.563(3.444)$ & $4.727-8.398$ & 7.622 & 0.000 \\
\hline
\end{tabular}

Table 3 The Pre-Post Mean Score Difference and Post Test Mean Score Difference Between Intervention and Control Group

\begin{tabular}{lcccc}
\hline \multicolumn{1}{c}{ Score } & Mean & SD & t & p \\
\hline Intervention Group Post test & 28.69 & 7.209 & -2.793 & 0.005 \\
Control Group Post test & 36.00 & 6.240 & & \\
Intervention Group Difference & 16.25 & 4.768 & 6.588 & 0.000 \\
Control Group Difference & 6.56 & 3.444 & & \\
\hline
\end{tabular}

Table 1 showed that generally both groups were dominated by pre elderly ages, females, blood glucose level less than $200 \mathrm{mg} \%$, normal body mass index, more than 4 weeks diabetic ulcers, and received antibiotic and insulin therapy. It also signified there was no significant different between both groups $(p>0.05)$ in terms of those characteristics.

The dependent $t$ test analysis suggested that mean of posttest score was significantly lower $(p=0.00)$ than mean of pretest score either in the intervention or control group. It is indicated there were significant improvement of diabetic ulcer healing in both groups.

The table noted that the posttest mean score in the intervention group was significantly lower $(p=0.005)$ than that in the control group. It indicated that diabetic ulcer wound healing score in the intervention group was significantly better than that in the control group. This finding also clarified by the further analysis that showed pre-posttest mean different score in the intervention group was significantly higher $(p=0.00)$ than that in 
Yeni Yulianti: Effects of Wound Care using Robusta Coffee Powders on Diabetic Ulcer Healing

the control group.

\section{Discussion}

This research proves that wound care using Robusta Coffee Powder as a complementary therapy has positive effect on diabetic ulcer healing. The result of this research supports the previous study findings conducted by Yuwono (2014) found that diabetic ulcers' healing process in Robusta Coffee Powder group is significantly faster than patients who received wound care using $\mathrm{NaCl} 0,9 \%$. However, our study applied different method of dressing. Yuwono (2014) washed the ulcers only for the first treatment then adding some coffee on the surface of ulcers. Coffee powders were changed daily for four weeks until the healing process occurred. In the other hand, in this study dressing technique applied Robusta Coffee Powder as the primer dressing and washed the ulcers using $\mathrm{NaCl}$ $0,9 \%$ before applied. The cleaning procedures of ulcers using $\mathrm{NaCl} 0.9 \%$ is performed every two days, but changing or adding new coffee is done every day.

The basic rational of the cleaning up the ulcers every couple days is to clean the ulcer surface from the debris and necrotic tissues. Atiyeh, Dibo, and Hayek (2009) noted that wound cleaning is an important factor in chronic ulcer treatment. This procedure effectively removes the debris, foreign bodies and necrotic tissue that inhibit wound healing process. Wound washing has been assumed as one of best methods to clean the ulcers. The liquid used for ulcer cleaning should be nontoxic, effective for reducing number of microorganism, and less causing hyper-sensitive reaction to the skin (Boateng, Matthews, Stevens, \& Eccleston, 2008).

In many cases, since chronic wound mostly develop biofilm and wide necrotic tissues, mechanical cleaning of wound bed using debridement techniques sometimes is required. The debridement to be the best option in managing biofilms (bacteria) that are resistance to the antibiotics use, either irrigated or topically applied (Jones, Cochrane, \& Percival, 2015). For this reason, the significant diabetic ulcer healing found in both groups in this study must be consider to be part of debridement effect. As presented earlier, $43.75 \%$ respondents in the intervention group and $25 \%$ respondent in the control group were recruited after performed debridement. Surgical debridement quickly changes the wound status from chronic wound into acute wound.

The diabetic ulcer conditions and healing are influenced by some factors: progressively hyperglycemia, pro-inflammatory, peripheral artery disease, and peripheral neuropathy. Fourth conditions above together causing the same malfunctioning immune cells, inflammatory responds become ineffective, endothel cell dysfunction, and choroidal disorder (Tellechea, Leal, Veves \& Carvalho, 2010). When the coffee applied on the ulcer, generally Coffee was assumed as one of natural materials which accelerate wound healing because it facilitates a TIME concept (Tissue Managemen, Infection or Inflamation control, Moisture balance, Edge of wound) in healing diabetic ulcers. There are some mechanisms that potentially improve ulcer healing. First, coffee applies tissue management by making ulcers become acid (Arimbi \& Yuwono, 2016).The area of ulcers which are relatively acid can destruct, the abnormal collagen from the base of ulcers, decrease the activity of protease (MMPs) by inhibiting spending of TNF a, improving angiogenesis, the activity of macrophages (Gethin, 2007). In terms of angiogenesis potent, it assumed able to help the hypoxia problem that commonly found in chronic wound. As commonly known, oxygen is required for fibroblasts replication, migration, run the function as well as collagen maturation. Therefore, wound healing process will impede in hypoxic condition (Hanson, Bents, \& Hematti, 2010; Kartika, 2005; Schreml et al., 2014).

Second, coffee identified able to control infection and inflammation because it contains CGA which is antibacterial (Z. Lou et al., 2011). The Robusta Coffee powders contain caffeine, chlorogenic acids (CGA), trigonelline, carbohydrate, fat, amino acids, organic acids, volatile aroma and $\mathrm{pH}$ mineral around 5.67-5.73. The acidic wounds area will reduce the activity of protease and stimulate tissue oxygenation. Additionally, it will reduce bacterial toxic substance (ammonia), destroy abnormal collagen in the ulcer base, 
Yeni Yulianti: Effects of Wound Care using Robusta Coffee Powders on Diabetic Ulcer Healing

increase angiogenesis, increase macrophage and fibroblast activity as well as control the activity of protease enzyme (Gethin, 2007).

CGA is assumed able to shorten inflammatory phase by inhabiting interleukin 6 (IL-6) releases. When the wound is able to come out from the inflammation phase then it goes to proliferation phase. This phase is started 2-3 days after the wound and is marked by fibroblast movement to the wound. Generally, it is overlapped with the inflammation phase, signed by epical a proliferation and migration above matrix in the ulcer (re-epithelializes). Inside dermis, fibroblast and endothelial cells seem stand out and support capillary development, collagen establishment, and the formation of granulation tissue. In the ulcer base, fibroblast produces collagen and also glycosaminoglycan as well as proteoglycan, which are the main a components of the extracellular matrix. Collagen and blood vessels are formed at the edges of the wound for supporting wound healing and wound closure (Lobmann, Schultz, and Lehnert, 2005).

The high contain of CGA in coffee has many advantages to produce pharmacological efficacy (Farhaty, 2017). CGA has biological function as antioxidant, inflammatory activity, and antibacterial because it prevents the development of positive and negative bacteria including staphylococcus aureus (Liang \& Kitts, 2015; Yaqin \& Nurmilawati, 2016). Chlorogenic acid (CGA) also contributes to reduce free radical and inhibit oxidation reaction and stimulate collagen synthesis by fibroblast, which contribute against the ulcers power (Alexandru et al., 2015). Additionally, CGA has the power of antioxidant activity by increasing dismutase superoxide, catalase, quotation and reducing the concentration of lipids, cell protein and nucleic acids. With antioxidant potent it able to keep the form of cell membrane and cell function through attacking antigen/infectious agents (dos Santos, Almeida, Lopes, \& de Souza, 2006; Hebeda et al., 2011; Winarsi, 2005). These mechanisms strengthen the effect of antibiotic therapy in supporting wound healing process. As the information presented earlier, all respondents in this study prescribed with antibiotic therapy. Therefore the significant healing process occurred in both groups should be carefully considered as part of the antibiotic therapy effect provided.

Third, coffee has potent to keep moist. Coffee powder absorbs exudates will beneficence in preventing over-moist conditions and further accelerates the healing process (Yuwono, 2014). This moist condition is basic strategy in managing any types of wound. Additionally, this potent also assumed provide benefit for edema management. The state of the tissue hypoxia can be caused by a state of edema on wounds in which edema condition in the wound enlarge the distance between capillaries, so the local oxygen perfusion will progressively reduce so that it impedes the process of wound healing (Hanson, Bents, \& Hematti, 2010; Kartika, 2005; Schreml et al., 2014).

Fourth, wound edge factors. The acid of caffeic, luteolin and apogent are the high antioxidants which stimulate collagen synthesis by fibroblast. These potent to further contribute on ulcers stability and strength. (Arimbi \& Yuwono, 2016; Liang \& Kitts, 2015; Yuwono, 2014).

This study also found that patients in the control group who received the conventional wound care using $\mathrm{NaCl} 0.9 \%$ dressing also showed significant diabetic ulcer healing. The conventional wound dressing applied moist $\mathrm{NaCl} 0.9 \%$ gauze and sometimes added with providence iodine $10 \%$ as primary dressing and dried gauze as secondary dressing. Principally, this dressing technique able to develop wound's moist environment that required for facilitating wound healing. However, the moist condition created by this technique inadequately longer. Additionally it requires changing and cleaning the wound daily that sometimes disturb new tissues growth. These disadvantages minimized the conventional dressing technique in improving diabetic ulcer healing (Ismail, Irawaty, \& Haryati, 2009). This lower effect in this study is clarified in the compared result of ulcer healing scores between control and intervention group.

Another therapy may contribute to this study's results is hyperglycemia management. Respondents in this study were prescribed insulin for maintaining their blood glucose. It also evident that most of patients 
Yeni Yulianti: Effects of Wound Care using Robusta Coffee Powders on Diabetic Ulcer Healing

showed controlled blood glucose level $(<200$ $\mathrm{mg} \%$ ). High blood glucose identified as the significant inhibiting wound healing factor. Leucocyte that run inflammation and fight the infection will unable to work well in the hyperglycemic conditions (Chodijah \& Pandelaki, 2013).

The age of respondents involved in this study also may contribute to the ulcer healing process in this study. As showed in respondents' characteristic most of respondents in this study were pre-elderly age, particularly in the control group. The different results may be found if the involved respondents come from elderly age. It is also commonly known that elderly age closely related to wound healing problem (Guo \& Dipietro, 2010).

\section{Research Limitation}

Some of diabetic ulcers observed in this study are post-surgical diabetic ulcers. This debridement process may contribute to the significant wound healing in both groups, since the surgical debridement performed provides ideal conditions for wound healing process by changing the state of the wound environment from chronic into acute conditions. Therefore, further studies are recommended to further clarify the effect of wound care using Coffee Robusta on diabetic ulcer healing with concern on controlling the confounding factors including debridement procedures.

\section{Conclusion}

This study is aimed to identify the effect of wound care using Coffee Robusta powders on diabetic ulcer healing. In conclusions, there is a significant effect of wound care using Robusta Coffee powders as a complementary therapy on diabetic ulcer healing. The effect is significantly larger compared to the conventional dressing using $\mathrm{NaCl} 0.9 \%$. It is important for healthcare professionals in Sekarwangi Hospital Sukabumi - West Java to consider this wound care technique to be part of diabetic ulcer management..

\section{References}

Aftria, M.P. (2014). Honey as a topical treatment for diabetic foot ulcers. Majority, 3(7). juke.kedokteran.unila.ac.id.

Alam, F., Islam, Md.A., Gan, S.H., \& Khalil, Md.I.. (2014). Honey: A potential therapeutic agentformanagingdiabetic wounds. EvidenceBased Complementary and Alternative Medicine. doi.org/10.1155/2014/169130.

Alexandru, V. et al. (2015). Phenolic content, antioxidant activity and effect on collagen synthesis of a traditional wound healing polyherbal formula. Studia Universitatis Vasile Goldis Seria Stiintele Vietii (Life Sciences Series), 25(1). Doi.org/281645225.

Arimbi, D., \& Yuwono, H.S. (2016). pH of wound fluids treated using coffee powder and bacitracin-neomycin powder. Global Journal of Surgery, 4(1), 9-11. doi: 10.12691/js-4-13 .

Atiyeh, B.S., Saad A. D., \& Shady, N. (2009). Wound cleansing, topical antiseptics and wound healing. International Wound Journal, 6(6), 420-30.

Boateng, J.S., Kerr, H.M., Howard N.E.S., \& Gillian, M.E. (2008). Wound healing dressings and drug delivery systems: A review. Journal of Pharmaceutical Sciences, 97(8), 2892-2923. DOI 10.1002/jps.21210.

Chodijah, S., Nugroho, A., \& Pandelaki, K. (2013). Hubungan kadar gula darah puasa dengan jumlah leukosit pada pasien diabetes mellitus dengan sepsis. Jurnal e-Biomedik, 1(1).

Dos, S., David, M., Almeida, M.C., Lopes, N.P., \& de Souza, G.E.P. (2006). Evaluation of the anti-inflammatory, analgesic and antipyretic activities of the natural polyphenol chlorogenic acid. Biological \& Pharmaceutical Bulletin, 29(11), 2236-40 https://doi.org/10.1248/bpb.29.2236.

Farhaty, N. (2017). Tinjauan kimia dan aspek farmakologi senyawa asam klorogenat pada 
Yeni Yulianti: Effects of Wound Care using Robusta Coffee Powders on Diabetic Ulcer Healing

biji kopi: Review. Farmaka, 14(3).

Frykberg, R.G., Thomas, Z., David, G.A., Vickie, R.D., M.S. John, M. Giurini, et al. (2006). Surgery diabetic foot disorders: A clinical practice guideline (2006 Revision) diabetic foot disorders, 1-66. doi. org/10.1016/S1067-2516(07)60001-5.

Gethin, Georgina. (2007). The significance of surface $\mathrm{pH}$ in chronic wounds. Wounds $U K$, $3(3), 52-56$.

Guo, S., \& L.A. Dipietro. (2010). Factors affecting wound healing. Obstetrics \& Gynecology (Mc 859), 219-30. doi: $10.1177 / 0022034509359125$.

Hanson, S.E., Michael L.B., \& Peiman, H. (2010). Mesenchymal stem cell therapy for nonhealing cutaneous wounds. Plastic and Reconstructive Surgery, 1252, 510. Doi: 10.1097/PRS.0b013e3181c722bb.

Hebeda, C.B. et al. (2011). Effects of chlorogenic acid on neutrophil locomotion functions in response to inflammatory stimulus. Journal of Ethnopharmacology, 135(2), 261-69. https://doi.org/10.1016/j. jep.2011.02.033.

Ismail, DDSL, D. Irawaty, \& T.S. Tutik Sri Haryati. (2009). Modern dressing improve the healing process in diabetic wound penggunaan balutan modern memperbaiki proses penyembuhan luka diabetik. Jurnal Penelitian Jurusan Keperawatan Fakultas Kedokteran Universitas Brawijaya.

Johnston, K.L., Michael, N.C., \& Linda, M.M. (2003). Coffee acutely modifies gastrointestinal hormone secretion and glucose tolerance in humans: Glycemic effects of chlorogenic acid and caffeine. The American Journal of Clinical Nutrition, 78(4), 728-33. https://doi.org/10.1093/ ajen/78.4.728.

Jones, E.M., Christine A.C., \& Steven, L.P. (2015). The effect of $\mathrm{pH}$ on the extracellular matrix and biofilms. Advances in Wound Care, 4(7), 431-39. https://doi.org/10.1089/ wound.2014.0538.
Kartika, R.W. (2015). Perawatan luka kronis dengan modern dressing. Teknik, 42(7), 54650 .

Kenisa, Y.P., \& Istiati, I. (2012). Effect of robusta coffee beans ointment on full thickness wound healing. Dental Journal (Majalah Kedokteran Gigi), 45(1), 52-57. https://doi.org/10.20473/j.djmkg.v45.i1.p5257.

Kumar, P., \& Thittamaranahalli, M.H. (2015). "Effect of limited access dressing on surface $\mathrm{pH}$ of chronic wounds. Plastic and Aesthetic Research, 2(5), 257.

Liang, N., \& David, D.K. (2015). Role of chlorogenic acids in controlling oxidative and inflammatory stress conditions. Nutrients, 8(1), 16. Doi:10.3390/nu8010016.

Lobmann, R., G. Schultz, \& H. Lehnert. (2005). Proteases and the diabetic foot syndrome: mechanisms and therapeutic implications. Diabetes Care, 28(2), 461-71. https://doi.org/10.2337/diacare.28.2.461.

Martyarini, S. A., \& Najatullah, N. (2011). Efekmadu dalam proses epitelisasi luka bakar derajat dua dangkal (Doctoral dissertation, Faculty of Medicine).

Perkeni.(2015).Pengelolaan danpencegahan diabetes melitus tipe 2 di Indonesia 2015.

Pillen, H. et al. (2009). Assessment of wound healing: Validity, reliability and sensitivity of available instruments. Wound Practice \& Research: Journal of the Australian Wound Management Association, 17(4), 208. http:// hdl.handle.net/2328/26498.

Schreml, S. et al. (2014). Luminescent dual sensors reveal extracellular $\mathrm{pH}$-gradients and hypoxia on chronic wounds that disrupt epidermal repair. Theranostics, 4(7), 721. Doi: $10.7150 /$ thno.9052.

Shaw, J., Ciara, M.H., Katie, M. L., Patrick, M.B., \& Michael, R.S. (2007). An evaluation of three wound measurement techniques in diabetic foot wounds. Diabetes Care, 30(10), 2641-42. https://doi.org/10.2337/dc07-0122. 
Yeni Yulianti: Effects of Wound Care using Robusta Coffee Powders on Diabetic Ulcer Healing

Sukohar, A., Firman, F., Wirakusumah, \& Herry, S.S. (2013). Isolation and characterization cytotoxic compounds caffeine and chlorogenic acid seeds of Lampung Coffee Robusta. Jurnal Medika Planta, 1(4).

Susanto, Y., Sugiarto, P., \& July, I. (2010). Efek serbuk biji kopi robusta (Coffea Robusta Lindl. Ex de Willd) terhadap waktu penutupan luka pada mencit jantan galur $\mathrm{Balb} / \mathrm{C}$ yang diinduksi aloksan. Jurnal Kedokteran Maranatha, 8(2), pp-121.

Tellechea, A., Leal, E., Veves, A., \& Carvalho, E. (2010). Inflammatory and angiogenic abnormalities in diabetic wound healing: role of neuropeptides and therapeutic perspectives. The Open Circulation \& Vascular Journal, 3(2), 43-55.
Whiting, D.R., Leonor, G., Clara, W., \& Jonathan, S. (2011). IDF diabetes atlas: Global estimates of the prevalence of diabetes for 2011 and 2030. Diabetes Research and Clinical Practice 94(3), 311-21. https://doi. org/10.1016/j.diabres.2011.10.029.

Yuwono, H.H.S. (2013). Serbuk kopi untuk mengobati luka paradigma baru dalam pengelolaan luka (Coffee powder for wound healing the new paradigm of wound management). Abstrak. http://repository. unpad.ac.id/id/eprint/21957.

Yuwono, H.S. (2014). The new paradigm of wound management using coffee powder. Global Journal of Surgery, 2(2), 25-29. 